\title{
Optimalisasi Pemanfaatan Lahan Pekarangan Untuk Mendukung Ketahanan Pangan Rumahtangga Petani Lahan Kering Di Desa Kayangan Lombok Utara
}

\author{
Jayaputra*, Nurrachman, Bambang Budi Santoso, I Komang Damar Jaya \\ Kelompok Peneliti Bidang Ilmu Pengembangan Pertanian Lahan Kering \\ Jurusan Budidaya Pertanian Fakultas Pertanian Universitas Mataram, Indonesia
}

\section{Article history \\ Received: 15 Maret 2020 \\ Revised: 25 Maret 2020 \\ Accepted: 11 Mei 2020 \\ *Corresponding Author: \\ Jayaputra}

Kelompok Peneliti Bidang Ilmu Pengembangan Pertanian Lahan Kering

Jurusan Budidaya Pertanian

Fakultas Pertanian Universitas

Mataram,

Mataram, NTB,

Indonesai;

Email: japut63@gmail.com.

\begin{abstract}
Agricultural land in Kayangan Village is mostly dry land with relatively low productivity and diversification of food production, which affects the income and supply of food that is not diverse and nutritious that affects the nutritional status of all family members and threatens household food security. However, the average household has a fairly large yard, which if properly designed and managed, will be able to meet the family's own food and nutrition needs, also has the opportunity to increase household income. The potential of the plots in the village of Heaven has not been managed properly, due to the low awareness of the importance of their plots, lack of knowledge and skills regarding proper yard management techniques to meet food and nutrition needs and family income. To overcome these problems, innovation technology transfer has been carried out through the development of environmentally friendly horticultural crops in optimizing the use of the yard to meet the nutritional needs and family income. Counseling and training / demonstration plots have been carried out during June-December 2019. Community service activities are considered quite successful in terms of the enthusiasm and perseverance of the participants in participating in this mentoring activity. The results of the demonstration plot showed a significant increase both in crop productivity and plant diversity that can be cultivated on the plots. Ongoing assistance from all parties, especially the local government, is expected to sustainably develop yard use to increase food availability and fulfill family nutrition, increase income and household food security of dry land farmers.
\end{abstract}

Keywords: cashew seeds; cashew nut; gumantar village

Abtrak: Lahan pertanian di Desa Kayangan sebagian besar merupakan lahan kering dengan produktivitas dan diversifikasi produksi pangan relatif masih rendah, yang berpengaruh terhadap pendapatan dan penyediaan pangan keluarga yang tidak beragam dan bergizi yang berdampak terhadap status gizi segenap anggota keluarganya dan mengancam ketahanan pangan rumahtangga. Namun, rata-rata rumah tangga memiliki pekarangan yang cukup luas, yang apabila dirancang dan dikelola dengan baik, akan dapat memenuhi kebutuhan pangan dan gizi keluarga sendiri, juga berpeluang meningkatkan penghasilan rumah tangga. Potensi lahan pekarangan di desa kayangan tersebut belum dikelola dengan baik, disebabkan rendahnya kesadaran akan arti penting lahan pekarangan yang dimiliki, kurangnya pengetahuan dan keterampilan mereka mengenai teknik pengelolaan pekarangan dengan baik untuk memenuhi kebutuhan pangan dan gizi serta pendapatan keluarga. Untuk mengatasi permasalahan tersebut, telah dilakukan transfer teknologi inovasi melalui pengembangan tanaman hortikultura ramah lingkungan dalam pemanfaataan lahan pekarangan secara optimal guna memenuhi kebutuhan gizi dan pendapatan keluarga. 
Penyuluhan dan pelatihan/demplot telah dilaksanakan selama Juni-Desember 2019. Kegiatan pengabdian kepada masyarakat ini dinilai cukup berhasil dilihat dari antusiasme dan ketekunan peserta dalam mengikuti kegiatan pendampingan ini. Hasil pelaksanaan demplot menunjukan peningkatan yang nyata baik pada produktivitas tanaman maupun keanegaragaman tanaman yang dapat dusahakan di lahan pekarangan. Pendampingan yang berkelanjutan dari semua pihak terutama pemerintah setempat sangat diharapkan untuk keberlanjutan pengembangan pemanfaatan lahan pekarangan guna meningkatkan ketersediaan pangan dan pemenuhan gizi keluarga, peningkatan pendapatan dan ketahanan pangan rumahtangga petani lahan kering.

Kata kunci: biji mete; kacang mete; desa gumantar

\section{PENDAHULUAN}

Desa Kayangan Kecamatan Kayangan Kabupaten Lombok Utara merupakan salah satu Desa Binaan Program Kemitraan dan Bina Lingkungan (PKBL) Universitas Mataram. Secara umum kondisi lahan pertanian di desa Kayangan merupakan lahan kering. Kegiatan usahatani yang diterapkan masyarakat tani di desa ini masih tradisional menurut kebiasaan yang berlanjut turun temurun baik dari teknik budidaya, sistem dan pola tanam maupun dari segi pemilihan tanaman yang diusahakan serta pengusahaannya tidak intensif dan belum berorientasi pasar. Kondisi ini tentu berpengaruh terhadap masih rendahnya produktivitas pertanian dalam arti luas yang dihasilkan oleh petani, sehingga akan berpengaruh terhadap rendahnya penghasilan mereka. Diversifikasi produksi pangan juga relatif masih rendah dan belum beragam, implikasinya adalah diversifikasi konsumsi pangan masyarakat juga belum beragam dan tidak berimbang.

Rendahnya diversifikasi konsumsi pangan tersebut dapat menyebabkan tidak berimbangnya asupan zat gizi masyarakat, tentu saja berimplikasi terhadap rendahnya status gizi masyarakat terutama pada golongan masyarakat yang beresiko tinggi seperti ibu hamil dan anak-anak balita. Di samping itu pemahaman rumah tangga petani di Desa Kayangan tentang peranan berbagai jenis pangan terhadap ketersediaan zat gizi, seperti sayuran dan buah-buahan dan pangan lainnya yang sebenarnya dapat mereka produksi sendiri dengan pemanfaatan potensi sumberdaya yang mereka miliki masih sangat rendah. Kondisi ini tentu berpengaruh terhadap upaya penyediaan pangan bagi keluarga yang tidak beragam dan bergizi yang dapat berdampak terhadap status gizi segenap anggota keluarganya. Jika kondisi ini terus berlanjut tentu akan mengancam ketahanan pangan rumahtangga.

Ketahanan pangan rumahtangga adalah kondisi terpenuhinya pangan bagi semua anggota rumahtangga, yang tercermin dari tersediannya pangan yang cukup, baik jumlah maupun mutunya, aman, beragam, bergizi, merata, dan terjangkau serta sesuai dengan keyakinan, dan budaya untuk dapat hidup sehat, aktif, dan produktif secara berkelanjutan. Pemantapan ketahanan pangan dapat dilakukan dengan peningkatan ketersediaan pangan di tingkat rumah tangga dengan mengembangkan komoditas lokal, peningkatan produktivitas pertanian melalui akselerasi pemanfaatan teknologi sesuai dengan kapasitas SDM setempat, pembinaan dan pendampingan secara intensif dan berkelanjutan pada program pemberdayaan masyarakat, menguatkan jejaring kerja dan komikomitmen seluruh pemangku kepentingan terhadap upaya peningkatan kesejahteraan masyarakat melalui peningkatan ketahanan pangan rumah tangga.

Ketersediaan pangan dalam jumlah yang cukup dan beragam sepanjang waktu merupakan keniscayaan yang tidak terbantahkan. Hal ini menjadi prioritas pembangunan pertanian nasional dari waktu ke waktu. Oleh karena itu, setiap rumah tangga diharapkan mengoptimalisasi sumberdaya yang dimiliki, termasuk pekarangan, dalam menyediakan pangan bagi keluarga. Pekarangan merupakan agroekosistem yang sangat baik serta mempunyai potensi yang tidak kecil dalam mencukupi kebutuhan hidup petani atau pemiliknya, bahkan kalau dikembangkan secara baik akan dapat bermanfaat lebih jauh lagi, seperti kesejahteraan masyarakat sekitar, dan pemenuhan kebutuhan pasar. Pekarangan yang berada di sekitar rumah tersebut dapat memberi tambahan hasil berupa bahan makanan seperti palawija, buah-buahan dan sayursayuran, kayu-kayuan baik untuk bahan kayu bakar maupun untuk kayu bahan bangunan. Oleh karena itu 
untuk meningkatkan penghasilan petani dan pemenuhan kebutuhan gizi masyarakat perlu memperhatikan arti penting lahan pekarangan. Lahan pekarangan rumah merupakan salah satu alternatif untuk mewujudkan ketahanan dan kemandirian pangan dalam rumah tangga.

Selain lahan sawah dan tegalan yang dimiliki rumah tangga petani di Desa Kayangan, rata-rata rumah tangga memiliki pekarangan yang cukup luas, namun potensi lahan pekarangan ini belum dikelola dengan baik, bahkan terkesan berantakan. Hal ini disebabkan karena masih rendahnya pemahaman dan kesadaran mereka akan arti penting lahan pekarangan yang dimiliki, di samping karena kurangnya pengetahuan dan keterampilan mereka tentang teknik pengelolaan pekarangan dengan baik untuk memenuhi kebutuhan pangan dan zat gizi serta sebagai tambahan pendapatan keluarga. Di sisi lain, kondisi lingkungan hidup rumah tangga petani di desa Kayangan, masih banyak ditemukan limbah rumahtangga, baik limbah cair maupun limbah padat, kotoran ternak dan sisa-sisa tanaman. Limbah-limbah tersebut tentu dapat mencemari lingkungan baik lingkungan fisik maupun kesehatan masyarakat, padahal bila dikelola dengan baik menggunakan teknologi tepat guna dapat memberikan manfaat sebagai bahan penyubur tanah (kompos) yang dapat digunakan sebagai input produksi dalam kegiatan pertanian dan pengelolaan pekarangan.

Kementerian Pertanian menginisiasi optimalisasi pemanfaatan pekarangan melalui konsep Rumah Pangan Lestari (RPL). RPL adalah rumah penduduk yang mengusahakan pekarangan secara intensif untuk dimanfaatkan dengan berbagai sumberdaya lokal secara bijaksana yang menjamin kesinambungan penyediaan bahan pangan rumah tangga yang berkualitas dan beragam. Apabila RPL dikembangkan dalam skala luas, berbasis dusun (kampung), desa, atau wilayah lain yang memungkinkan, penerapan prinsip Rumah Pangan Lestari (RPL) disebut Kawasan Rumah Pangan Lestari (KRPL). Selain itu, KRPL juga mencakup upaya intensifikasi pemanfaatan pagar hidup, jalan desa, dan fasilitas umum lainnya (sekolah, rumah ibadah, dan lainnya), lahan terbuka hijau, serta mengembangkan pengolahan dan pemasaran hasil. Tujuan penting yang ingin di capai dalam pengembangan program KRPL ini antara lain : meningkatkan keterampilan keluarga dan masyarakat dalam pemanfaatan lahan pekarangan, memenuhi kebutuhan pangan dan gizi keluarga dan masyarakat secara lestari, mengembangkan kegiatan ekonomi produktif keluarga serta menciptakan lingkungan hijau yang bersih dan sehat secara mandiri. Untuk menunjang keberhasilan masyarakat dalam memanfaatkan pekarangan sebagai penyuplai gizi keluarga perlu dilakukan upayaupaya sehingga makna lestari seperti yang dicanangkan pada program KRPL tercapai.

Pengelolaan dalam rangka intensifikasi pekarangan tidak dapat dipisahkan dari beberapa prinsip sehubungan dengan perbaikan gizi masyarakat dengan memperhatikan kondisi sosial ekonomi masyarakat pelaksana intensifikasi tersebut. Oleh karena itu, untuk keberhasilan pengelolaannya, program intensifikasi pekarangan perlu dilandasi oleh sekurang-kurangnya empat prinsip, yaitu:

1) tata pertanaman

2) prinsip biaya pengelolaan yang rendah

3) prinsip kesinambungan, dan

4) pengembangan tanaman-tanaman yang bergizi tinggi.

Berdasarkan uraian dia atas, maka telah dilakukan kegiatan pengabdian kepada masyarakat sebagai upaya untuk meningkatkan pengetahuan dan keterampilan rumah tangga petani di desa Kayangan khususnya dusun Beraringan dalam mengelola sumberdaya lahan lahan pekarangan guna mendapatkan manfaat yang sebesar-besarnya bagi penuhan kebutuhan gizi keluarga dan mendukung ketahanan pangan rumahtangga. Program pengabdian kepada masyarakat ini dilaksanakan sejak bulan Juni 2019 sampai dengan bulan Desember 2019, bertujuan untuk: 1) Melakukan transfer teknologi melalui kegiatan penyuluhan, pelatihan/ demplot, dan pendampingan masyarakat dalam rangka pemanfaatan lahan pekarangan secara optimal untuk memenuhi kebutuhan pangan dan gizi keluarga dan meningkatkan ketahanan rumahtangga berbasis komoditas hortikultura sebagai tanaman unggulan di desa Kayangan yang berakar pada kemampuan sumberdaya lokal yang ada; 2) Meningkatkan kapasitas petani khususnya kelompok wanita tani melalui bimbingan teknis dalam pengelolaan lahan pekarangan yang berkelanjutan dengan komoditas hortikultura sebagai komoditi andalan, serta 3) Meningkatkan status ekonomi masyarakat dengan mengembangkan potensi daerah melalui kegiatan transfer teknologi yang berkelanjutan. 


\section{METODE}

Kegiatan pengabdian kepada masyarakat ini dilaksanakan Dusun Beraringan Desa Kayangan Kecamatan Kayangan Kabupaten Lombok Utara. Peserta kegiatan adalah anggota Kelompok Wanita Tani Putri Redilam sebanyak 20 orang. Penentuan peserta binaan ini dilakukan oleh ketua Kelompok Wanita Tani Putri Redilam dan Tim PPM Kelompok Peneliti Pertanian Lahan Kering Fakultas Pertanian Universitas Mataram. Peseta binaan yang dipilih adalah anggota kelompok wanita tani yang mempunyai motivasi untuk mengikuti kegiatan optimalisasi pemanfaatan lahan pekarangan dengan basis pengembangan pangan lokal dan komoditas hortikultura sebagai komoditi andalan.

Sesuai dengan target luaran, maka dilakukan pengumpulan data dengan menggunakan metode observasi. Pelaksanaan kegiatan pengabdian kepada masyarakat ini menggunakan metode pendekatan sosial yang menempatkan masyarakat binaan sebagai subyek kegiatan dan metode kaji terap partisipatif (Participatory Action Reseach) pada tahap pelatihan kelompok tani binaan, dan praktik demonstrasi plot (demplot) untuk percepatan alih teknologi dan pembinaan langsung oleh tim pelaksana.

Pemberdayaan masyarakat dengan metode ini pada dasarnya adalah upaya pelibatan masyarakat untuk belajar dan beraktivitas secara berkelanjutan dalam rangka meningkatkan kualitas hidup mereka. Oleh karena itu, dalam kegiatan pengembangan hortikultura lahan kering yang berkelanjutan, masyarakat mulai dilibatkan dalam kegiatan perencanaan program, pelaksanaan program, pemanfaatan hasil program dan evaluasi terhadap pelaksanaan program. Dengan cara seperti ini, maka diharapkan kegiatan kaji terap partisipatif dalam pengembangan hortukultura lahan kering yang tersusun adalah program yang sesuai dengan kebutuhan masyarakat.

Kegiatan Penyuluhan akan dilaksanakan dengan cara ceramah disertai dengan presentasi menggunakan Power Point dan dikuti diskusi/ tanya jawab. Presentasi Power Point dimaksudkan untuk mempertegas maksud dari ceramah dan meberikan contoh-contoh teknik pengelolaan pekarangan yang sesuai dengan potensi sumberdaya setempat dengan menampilkan secara visual penerapan berbagai teknologi tepat guna dalam budidaya tanaman hortikultura di lahan pekarangan.

Selain dilakukan ceramah dan diskusi, kegiatan dilanjutkan dengan pelatihan/ demplot penerapan berbagai teknologi yang dapat digunakan dalam pengelolaan pekarangan yang ditawarkan, di antaranya teknik vertikultur, budidaya dalam wadah (polibag), teknik No Dig Plot, teknik budidaya hamparan, budidaya berbagai komoditas tanaman hortikultura yang disesuaikan dengan kebutuhan masyarakat setempat dan pasar, serta pemanfaatan limbah rumahtangga, sisa-sisa tanaman, kotoran ternak untuk pembuatan kompos dan pengenalan tanaman lokal setempat yang potensi untuk pestisida hayati.

Untuk melakukan bimbingan secara intensif pada setiap kegiatan yang dilakukan oleh kelompok petani mitra binaan, maka dilakukan pendampingan di lapangan. Tim PPM Fakultas Pertanian Universitas Mataram berperan sebagai tenaga ahli yang melakukan transfer pengetahuan dan teknologi di lapangan yang dilakukan secara berkala.

Evaluasi merupakan kegiatan akhir program pengabdian kepada masyarakat. Evaluasi dilakukan terhadap peran dan keterlibatan peserta, antusiasme serta serapan peserta terhadap kegiatan penyuluhan, demplot dan bimbingan yang telah dilakukan. Tanggapan peserta terhadap keseluruhan rangkaian kegiatan PPM ini dan keinginan untuk menerapakannya pada lahan pekarangan masing-masing rumahtangga petani menjadi tolok ukur utama keberhasilan kegiatan pengabdian kepada masyarakat ini.

\section{HASIL DAN PEMBAHASAN}

Sesuai dengan tujuan yang telah ditetapkan dan metode pelaksanaan kegiatan, pelaksanaan program pengabdian kepada masyarakat ini dilaksanakan dengan tahapan sebagai berikut:

\section{Tahap persiapan}

Tahap persiapan dimulai sejak bulan Juni 2019 sampai bulan Juli 2019 atau menjelang pelaksanaan kegiatan penyuluhan dan pelatihan/demplot. Pada tahap ini, telah dilakukan pendekatan- pendekatan dengan berbagai unsur dalam masyarakat seperti tokoh masyarakat, tokoh pemuda, kelompok tani dan pemerintahan 
desa. Beberapa hal yang dilakukan pada tahap persiapan meliputi:

a. Observasi dan Sosialisasi program kegiatan kepada masyarakat. Kegiatan ini dilakukan untuk mengidentifikasi potensi wilayah dan penyamaan persepsi dengan berbagai unsur dalam masyarakat seperti tokoh masyarakat dan pemerintahan desa. Penyamaan persepsi ini berkaitan dengan potensi sumberdaya manusia dan potensi sumberdaya alam yang bisa dan akan dikembangkan oleh masyarakat, kondisi sosial ekonomi, budaya, pola pemanfaatan lahan pekarangan yang sudah dilaksanakan oleh masyarakat, teknologi tepat guna dalam budidaya di pekarangan untuk meningkatkan produktivitas, peluang pasar, SDM, keterampilan, pengetahuan dan sarana prasarana pendukung lainnya.

b. Penetapan peserta yang akan menjadi mitra binaan sasaran program kegiatan kegiatan pengabdian kepada masyarakat. Peserta binaan yang dipilih adalah mereka yang mempunyai motivasi untuk mengikuti kegiatan optimalisasi pemanfaatan lahan pekarangan dengan basis pengembangan komoditas hortikultura sebagai komoditi andalan dan memiliki kemauan untuk memperbaiki teknologi budidaya tanaman di pekarangan guna meningkatkan produktivitas lahan pekarangannnya. Penentuan petani binaan ini dilakukan oleh ketua kelompok tani sesuai saran dan persyaratan yang telah ditetentukan oleh Tim Pelaksana.

c. Penetapan waktu pelaksanaan kegiatan penyuluhan dan pelatihan/ demplot Optimalisasi pemanfaatan lahan pekarangan. Pelaksanaan penyuluhan disepakati dilakukan tanggal 21 Juli 2019 dan pelaksanaan Demplot dilaksanakan pada bulan September 2019.

d. Persiapan/pengadaan bahan dan alat untuk kegiatan penyuluhan dan demplot.

\section{Tahap Pelaksanaan}

Tahap pelaksanaan meliputi kegiatan Penyuluhan, Pelatihan/ Demplot, pendampingan, monitoring dan evaluasi.

a. Penyuluhan. Kegiatan penyuluhan dilakukan pada tanggal 21 Juli 2019 yang berlangsung sejak pukul 16.00 sampai pukul18.15 di dusun beraringan desa kayangan, dengan menyampaikan materi secara langsung oleh Tim PPM yang diikuti diskusi/ tanya jawab terhadap materi yang disampaikan dan permasalahan yang dialami masyarakat sasaran dalam pengelolaan lahan pekarangan, teknologi tepat guna dalam budidaya dan

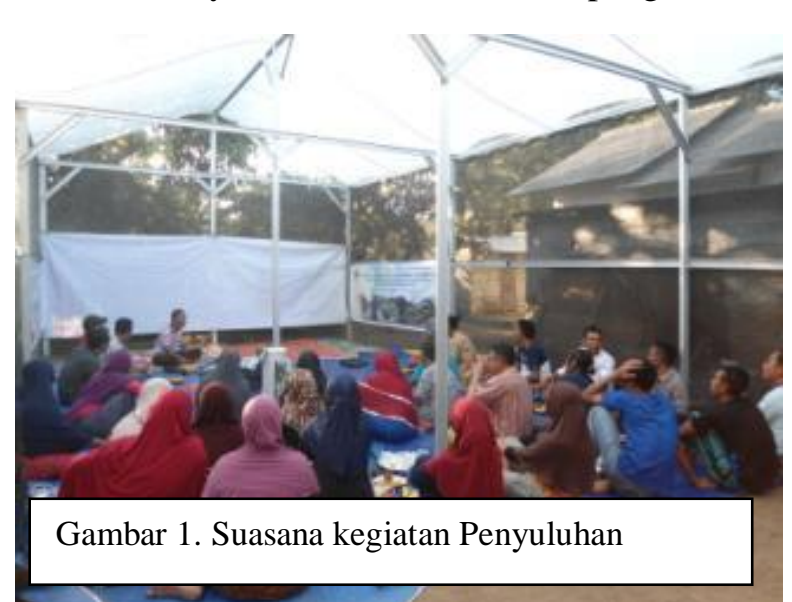
pengembangan tanaman hortikultura di lahan pekarangan. Penyampaian materi penyuluhan dilakukan melalui media dalam bentuk powerpoint yang ditanyangkan melalui LCD proyektor. Presentasi Power Point menampilkan secara visual penerapan berbagai teknologi tepat guna dalam budidaya tanaman hortikultura di lahan pekarangan. Materi penyuluhan meliputi berbagai teknologi tepat guna yang dapat digunakan dalam pengelolaan pekarangan, di antaranya teknik vertikultur, budidaya dalam wadah (polibag), teknik No Dig Plot, teknik budidaya hamparan, budidaya berbagai komoditas tanaman hortikultura yang disesuaikan dengan kebutuhan masyarakat setempat dan pasar, serta pemanfaatan limbah rumahtangga, sisa-sisa tanaman, kotoran ternak untuk pembuatan kompos dan pengenalan tanaman lokal setempat yang potensi untuk pestisida hayati.

b. Pelatihan dan Demplot. Pelatihan/ Demplot Pembuatan Kompos dan Budidaya tanaman di Pekarangan. Pelaksanaan kegiatan pelatihan/ demplot pemanfaatan limbah rumahtangga, sisa-sisa tanaman, kotoran ternak untuk pembuatan kompos dan pengenalan tanaman lokal setempat yang potensi untuk pestisida hayati dilakukan berselang 1 (satu) minggu belatihan/rikutnya setelah kegiatan penyuluhan dilaksanakan sesuai kesepakatan dan untuk mempersiapkan bahan-bahan dan alat yang diperlukan untuk kegiatan demonstrasi. Sedangkan demplot penerapan teknologi tepat guna dalam budidaya ramah lingkungan/ pertanian organik 
berbagai komoditas tanaman hortikultura (tomat, cabai, terong sawi, kangkung, selada dan pare) di lahan pekarangan (demplot teknik budidaya) dilaksanakan 1 bulan kemudian setelah kegiatan demplot pembuatan kompos, sambil menunggu kesiapan penanaman, wadah dan media tanam (rancangan model penanaman, pembuatan rak, pengisian polibag dengan media tanam dan pembibitan). Tujuan dari kegiatan ini adalah untuk meningkatkan pengetahuan dan pemahaman dan keterampilan kelompok masyarakat sasaran tentang cara-cara melakukan pembuatan pupuk organik dan pestisida hayati serta teknik budidaya tanaman secara organik dengan mengembangkan berbagai jenis tanaman hortikultura terutama sayur-sayuran di lahan pekarangan menggunakan polibag. Pelatihan/ demonstrasi dilakukan dengan memberikan petunjuk dan praktek langsung dalam hal teknik pembuatan pupuk organik dan teknik budidaya tanaman secara organik di lahan pekarangan menggunakan polibag, dimulai dari persiapan bahan dan alat, pembuatan kompos, pencampuran bahan untuk wadah dan media tanam, persemaian, pengisian polibag dengan media tanam, penanaman, , pengaturan media tanam dan penerapan model penanaman. Sasaran pelatihan/ demonstrasi pembuatan pupuk organik adalah untuk digunakan sebagai bahan pemupukan tanaman hortikultura yang diusahakan. Sedangkan pengembangan komoditi tanaman hortikultura terutama sayuran baik di lahan pekarangan menggunakan polibag ditujukan sebagai salah satu alternatif upaya diversifikasi komoditas tanaman yang dapat dikembangkan di lahan kering untuk meningkatkan pendapatan dan memenuhi kebutuhan pangan dan gizi keluarga sehari-hari.

Bahan dan alat untuk keperluan demonstrasi telah dipersiapkan sebelumnya oleh TIM pengabdian kepada masyarakat, seperti: starter untuk pengomposan (EM-4 dan stardec), benih sayuran tomat, melon, cabai, sawi, selada, dan benih sayuran lainnya, polibag, hand sprayer, contoh kompos, pupuk dan pestisida organik. Sementara alat dan bahan lainnya disiapkan masyarakat peserta seperti cangkul, media tanah, kotoran ternak bambu dan lain-lain. Demplot teknik budidaya tanaman di lahan pekarangan dilakukan di lahan pekarangan ketua kelompok wanita tani. Bersamaan dengan kegiatan demplot, beberapa orang dari anggota kelompok wanita tani peserta binaan juga melakukan persiapan untuk kegiatan serupa pada lahan pekarangan masing-masing yang mereka lakukan setelah menerima materi pelatihan/demplot. Dalam pelaksanaan kegiatan pelatihan/ demontrasi pembuatan pupuk organik (kompos) dan teknik budidaya tanaman berbasis pertanian organik di lahan pekarangan, respon peserta cukup besar, hal ini dapat dilihat dari keseriusan dan ketekunan seluruh peserta untuk mengikuti proses pelatihan/ demonstarasi tersebut.

c. Monitoring dan Pendampingan. Dalam rangka menindaklanjuti kegiatan penyuluhan dan pelatihan/ demonstrasi tersebut, TIM pelaksana pengabdian kepada masyarakat melakukan monitoring secara berkala dan berkelanjutan untuk memberikan arahan dan mengatasi masalah yang dihadapi masyarakat sasaran berkaitan dengan pengelolaan tanaman secara organik di lahan pekarangan. Kegiatan pendampingan dan monitoring dilakukan setelah pelaksanaan penyuluhan, pelatihan dan demplot. Untuk duplikasi demplot di pekarangan masing-masing peserta binaan, TIM PPM Unram menyiapkan dan membagikan paket awal berupa polibag, pupuk organik cair (Bioektrim, organok dan Super Biota Plus) dan pestisida organik (Bomax). Semua peserta binaan melakukan kegiatan duplikasi di pekarangan masing-masing dengan kreasi dan model penataan dan penanaman sesuai dengan keterdiaan bahan pendukung yang ada dan kemampuan yang mereka miliki, seperti pembuatan rak untuk penanaman vertikultur, penanaman sistem hamparan, pemanfaatan botol bekas, kaleng cat, karung bekas dan lai-lain. Meskipun dengan keterbatasan sumberdaya yang mereka miliki akibat dampak gempa tahun 2018, mereka melaksanakan kegiatan pemanfaatan pekarangannya dengan penuh semangat di antara kesibukan mereka sehari hari yang masih dalam tahap pemulihan. Tim PPM secara berkala 2 minggu sekali melakukan pendampingan dan momonitor hasil kegiatan pemanfaatan pekarangan di setiap peserta binaan dengan memberikan arahan / solusi dari permasalahan yang mereka hadapi dalam mengoptimalkan pemanfaatan pekarangan, memberikan contoh/praktek budidaya yang benar sesuai dengan pertumbuhan dan perkembangan tanamannya, pemeliharaan dan pengaturan faktor lingkungan yang berpengaruh. Selain pendampingan dan monitoring yang dilakukan oleh TIM PPM Unram, kegiatan pendampingan dan pemantauan harian secara rutin dilakukan oleh bapak kepala lingkungan dan ketua kelompok wanita tani untuk selalu menyemangati mereka dan menampung berapa keluhan/ kendala peserta binaan dalam pengelolaan pekarangannya dan untuk selanjutnya diteruskan kepada TIM PPM sebagai bahan/ 
masukan dalam rangka mengatasi setiap permasalahan yang dihadapi yang dapat tanggapi secara langsung atau pada saat kunjungan pendampinga/ monitoring selanjutnya.

d. Keragaan dan Hasil Pemanfaatan Pekarangan. Berkat kerjasama yang baik dari semua pihak, kegiatan pemanfaatan pekarangan berjalan dengan baik dengan hasil yang cukup memuaskan. Semua peserta binaan dinilai berhasil dalam menerapkan teknologi budidaya di lahan pekarangannya, meskipun pada beberapa bagian teknik budidaya dan pengelolaan pekarangan perlu ada perbaikan guna lebih mengoptimalkan pemanfaatan lahan pekarangannya. Untuk menunjang keberlanjutan kegiatan penananam/ budidaya, telah disepakati untuk mebangun kebun bibit kelompok dengan tujuan agar ketersediaan bibit selalu siap saat dibutuhkan oleh peserta bianaan untuk penanaman selanjutnya atau mengganti dan menambah tanaman yang ingin diusahakan. Kebun bibit kelompok ini dikelola oleh ketua kelompok wanita tani dan anggota dengan modal awal diberikan oleh TIM PPM berupa benih berbagai macam sayuran, gembor dan hand sprayer. Selanjutnya pengaturan sistem pembagian/ pengambilan bibit di Kebun Bibit Kelompok diatur dengan aturan kesepakatan bersama dengan sisitem gotong royong sehingga keberlanjutan kebun bibit dapat dipertahankan. Kesepakatan aturan kelompok juga menyangkut sistem pemasaran hasil pekarangan bagi peserta yang mampu menghasilkan produksi melebihi kebutuhan keluarga. Dalam hal ini pemasaran hasil pekarangan ditangani oleh ketua kelompok wanita tani yang secara kebetulan juga sebagai pengepul hasil pertanian petani di dusun beraringan kecamatan kayangan.

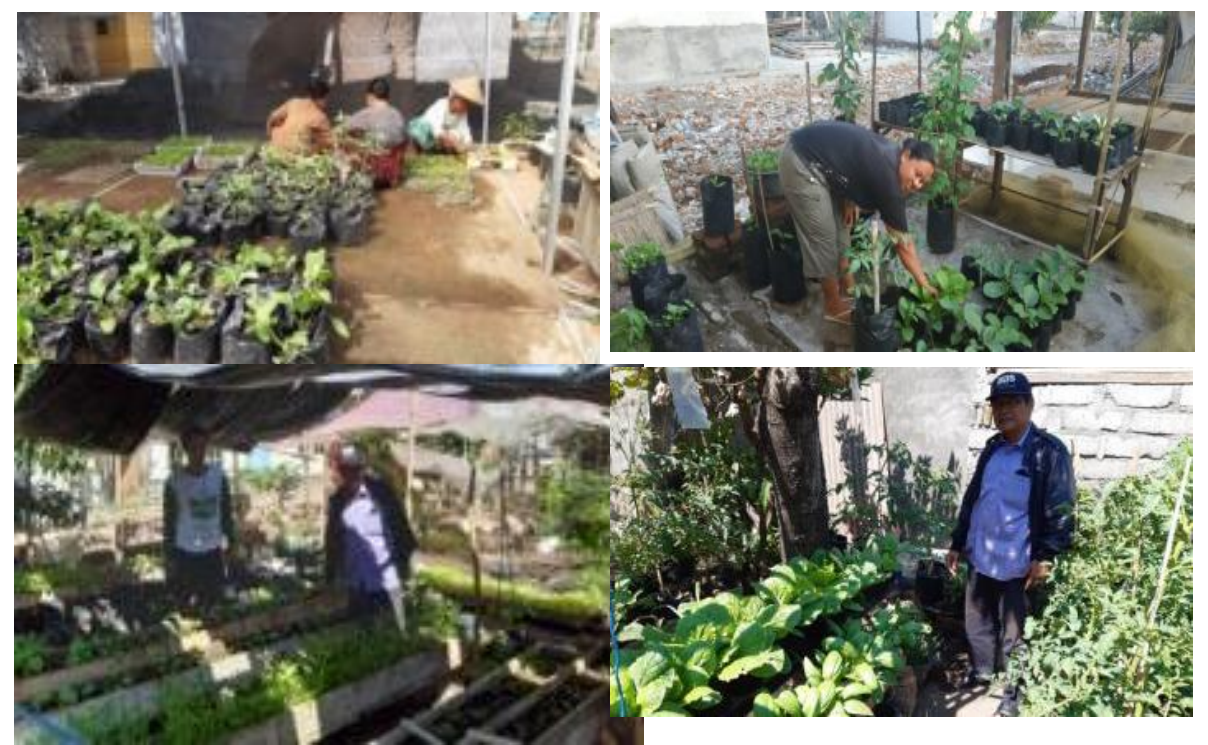

Gambar 2. Kegiatan pengabdian kepada masyarakt, searah jarum jam dari atas, kegiatan di kebun bibit kelompok dan keragaan pertumbuhan tanaman hasil demplot selama kegiatan pengabdian kepada masyarakat di Dusun Beraringan, Desa Kayangan

\section{Tahap Evaluasi}

Evaluasi merupakan kegiatan akhir program pengabdian kepada masyarakat yang dilakukan terhadap peran dan keterlibatan peserta, antusiasme serta serapan peserta terhadap materi kegiatan penyuluhan, demplot dan bimbingan yang telah dilakukan. Dalam pelaksanaan kegiatan ini tidak mendapatkan hambatan yang berarti, namun karena tingkat pendidikan dan pengalaman para peserta yang berbeda-beda, sehingga respon mereka terhadap penerimaan materi juga berbeda-beda. Untuk mengatasi masalah tersebut, penyampaian materi harus dilakukan dengan bahasa yang sederhana dan lebih banyak menggunakan bahan peraga atau lebih banyak menunjukkan contoh - contoh kasus secara langsung. Minat dan perhatian peserta dalam mengikuti kegiatan penyuluhan dan pelatihan/demplot yang cukup tinggi 
merupakan faktor pendorong yang kuat dalam proses penyelenggaraan kegiatan pengabdian kepada masyarakat ini. Disamping itu adanya dukungan dari aparat desa terutama dari Kepala Desa dan Kepala Dusun, dan tokoh masyarakat yang cukup kuat.

Dari hasil pengamatan selama berlangsungnya kegiatan penyuluhan, demplot dan pendampingan dapat disimpulkan beberapa hal sebagai berikut:

1. Respon peserta penyuluhan cukup besar, hal ini dapat dilihat dari keseriusan dan ketekunan seluruh peserta untuk mengikuti proses penyuluhan. Hal ini tentu dapat menjadi bekal tambahan pengetahuan mereka terkait upaya optimalisasi lahan pekarangan yang mereka miliki melalui pengembangan tanaman hortikultura dan teknologi budidayanya.

2. Materi yang disampaikan cukup relevan dengan kebutuhan peserta, dan mudah dimengerti oleh peserta, hal ini dapat dilihat dari diskusi dan pertanyaan-pertanyaan yang diajukan oleh peserta cukup relevan dengan topik yang dibahas dan dipraktikkan.

Waktu yang disediakan dalam kegiatan ini terutama untuk dialog saat berlangsungya penyuluhan dirasa kurang, sehingga para peserta merasa sangat perlu untuk menindak lanjuti pertemuan tersebut. Oleh karena itu dukungan dari pemerintah setempat terutama dari aparat desa dan PPL sangat diperlukan untuk memfasilitasi penyelenggaraan tindak lanjut pertemuan dan pembinaan selanjutnya.

\section{KESIMPULAN DAN SARAN}

Perubahan prilaku masyarakat dalam pengelolaan lahan pekarangan dengan berbagai komoditas pangan khususnya bercocok tanam tanaman hortikultura yang baik merupakan tujuan dari pemberdayaan ini. Oleh karena itu, proses ini membutuhkan waktu yang lama untuk menilai apakah program ini sudah dapat dinilai berhasil atau tidak. Namun demikian dilihat dari antusiasme dan ketekunan peserta selama penyuluhan dan pelatihan, serta demplot, maka kegiatan pengabdian kepada masyarakat ini dapat dinilai cukup berhasil.

Teknologi budidaya tanaman khususnya tanaman hortikultura dalam rangka optimalisasi pemanfaatan lahan pekarangan bagi masyarakat sasaran merupakan suatu hal yang dianggap sebagai inovasi atau teknologi baru. Sehingga melalui penyuluhan dan pelatihan, serta demplot yang telah dilakukan oleh tim PPM diharapkan bahwa inovasi dan teknologi ini mampu diadopsi oleh masyarakat sasaran guna mendukung ketahanan pangan rumahtangga.

Kegiatan PPM dalam rangka optimalisasi pemanfaatan lahan pekarangan melalui pengembangan tanaman hortikultura di lahan pekarangan dengan teknologi budidaya yang sesuai dalam rangka penyediaan pangan dan peningkatan pendapatan rumahtangga seperti ini perlu dilakukan secara berkelanjutan sehingga dapat terinternalisasi dalam kehidupan masyarakat. Inovasi dan teknologi tersebut bukan hanya teradopsi oleh peserta penyuluhan dan pelatihan, serta demplot, tetapi diharapkan mampu direplikasi oleh masyarakat yang berminat untuk mengembangkan, bahkan diharapkan terjadi proses diffusi inovasi di kalangan masyarakat luas.

\section{DAFTAR PUSTAKA}

Anonim. 1981. Usaha Meningkatkan Potensi Pekarangan Di Desa Sekitar Hutan. Informasi Pertanian, DEPTAN. Balai Informasi Kayuambon, Lembang, Jabar.. (5):3-6

Danoesastro, H. 1973. Kemungkinan Peningkatan Pertanaman Pekarangan. Penataran Purna Sarjana Penyuluhan Pertanian UGM ke II, Yogyakarta. 11 hal.

Danoesastro, Haryono. 1978. "Tanaman Pekarangan dalam Usaha Meningkatkan Ketahanan Rakyat Pedesaan”. Agro - Ekonomi. Maret. 1979. Pemanfaatan Pekarangan. Yayaan Pembina Fakulas Pertanian UGM. Yogyakarta.

Djuarnani, N., Kristian B. S., Setiawan. 2005. Cara Cepat Membuat Kompos. Agromedia Pustaka. Higa, T. 1998. Materi Latihan Teknologi EM. Departemen Pertanian, Jakarta.

Garnadi, A. 1972. Tanaman Pekarangan Membawa Keuntungan. Majalah Pertanian (12); 1-42. 
Naniek Siti Murdjati. 1978. Peranan Pekarangan Dalam Mencukupi Kebutuhan Sehari-hari Masyarakat Pedesaan. Makalah Seminar Mahasiswa Agronomi UGM. 11 hal.

Rizal, M dan Fiana, Y. 2015.Teknologi Budidaya Tanaman Sayuran dan Toga di Perkotaan dan Pedesaan pada Kawasan Rumah Pangan Lestari dalam mendukung Ketahanan Pangan di Kalimantan Timur. Prosiding Seminar Nasional Masyarakat Biodiversitas Indonesia. Volume 1, Nomor 2, April2015.

Suwarno, R. 1975. Peranan Pekarangan dalam Kehidupan Sehari-hari. Majalah Pertanian (1) : 1-45.

Wibowo, R. 2000. Pertanian dan Pangan, Bunga Rampai Pemikiran menuju Ketahanan Pangan. Sinar Harapan. Jakarta.

Zainuri, Taslim sjah, Jayaputra dan Ahmad Sauqi. 2017. Pengembangan Agrowisata Melalui Sistem Agribisnis Dan Agroindustri Terpadu Untuk Mendukung Pariwisata Dan Ekonomi Desa Kayangan Kabupaten Lombok Utara. Laporan Penelitian MP3EI Tahun ke 2. Universitas Mataram. 